\title{
ANALISIS PRODUK PEMBELAJARAN MENULIS BAHAN AJAR BERBASIS KKNI
}

\author{
Beslina Afriani Siagian \\ Pendidikan Bahasa dan Sastra Indonesia \\ Fakultas Keguruan dan Ilmu Pendidikan \\ Universitas HKBP Nommensen \\ beslinasiagian@uhn.ac.id
}

\begin{abstract}
Abstrak
Penelitian ini merupakan penelitian deskiptif kualitatif yang bertujuan untuk melakukan analisis terhadap produk pembelajaran mata kuliah Menulis Bahan Ajar sesuai dengan KKNI. Adapun produk yang dianalisis adalah hand out, modul dan LKPD (Lembar Kegiatan Peserta Didik). Ketiga produk tersebut disesuaikan dengan Kerangka Kualifikasi Nasional Indonesia (KKNI). Penelitian ini menggunakan pendekatan kualitatif dengan metode deskriptif. Subjek penelitian adalah seluruh mahasiswa stambuk 2016 yang mengukti mata kuliah Menulis Bahan Ajar. Data dikumpulkan berdasarkan teknik penugasan dan ditegaskan dengan metode observasi dan wawancara tertulis. Berdasarkan hasil penelitian diperoleh nilai penulisan hand out ada pada grade A sebanyak 35,2\%, penulisan modul sebanyak $68,23 \%$, dan penulisan LKPD sebanyak 72,9\%. Artinya, mahasiswa sudah mampu menghasilkan produk dalam mata kuliah Menulis Bahan Ajar yang sudah disesuaikan dengan Kerangka Kualifikasi Nasional Indonesia (KKNI).
\end{abstract}

Kata kunci: KKNI, Bahan Ajar, Modul, Hand Out, LKPD

\section{A. PENDAHULUAN}

KKNI memuat deskripsi membentuk konektivitas antara kualifikasi yang diinternalisasi dalam kompetensi yang diperoleh lulusan bentuk pengetahuan, sikap, dengan kebutuhan pemangku keterampilan umum dan keterampilan kepentingan. Tujuan utamanya adalah khusus. Hal itu menjadi wadah dalam untuk menyetarakan sumber daya 
manusia yang ada di Indonesia dengan yang ada di belahan dunia lain dalam hal pendidikan dan pelatihan kerja di berbagai sektor.

Dalam hal ini, program studi Pendidikan Bahasa dan Sastra Indonesia FKIP Universitas HKBP Nommensen telah mencoba memuat beberapa deskripsi kualifikasi dalam sebaran mata kuliah. Perubahan substansi dan bobot pada setiap mata kuliah tentu tampak pada kurikulum berbasis KKNI, seperti penambahan bobot SKS pada mata kuliah Linguistik Umum, penambahan substansi pada mata kuliah Keterampilan Membaca Teknik dan Kreatif, Keterampilan Berbicara Interpersonal dan Interaktif, Keterampilan Menulis Kritis dan Ilmiah serta penambahan mata kuliah Kewirausahaan, BIPA (Bahasa Indonesia untuk Penutur Asing), Menulis Bahan Ajar.

Menulis Bahan Ajar merupakan mata kuliah yang memuat capaian pembelajaran mampu menulis dan mengembangkan bahan ajar, seperti modul, hand out, dan LKPD (Lembar Kegiatan Peserta Didik). Mata kuliah ini tidak mudah dikerjakan jika mata kuliah sebelumnya yang berkaitan dengan pendidikan dan kurikulum tidak diperoleh siswa dengan mumpuni. Selain itu, muncul pertanyaan baru terkait KKNI yang perlu diperhatikan, yakni: apakah deskripsi kualifikasi yang dimuat dalam mata kuliah tersebut dapat diaplikasikan dalam pembelajaran? Apakah kompetensi lulusan yang diharapkan dapat diperoleh dengan menerapkan KKNI? Perangkat pembelajaran seperti apa yang harus digunakan dalam mewadahi deskripsi kualifikasi KKNI?

Pertanyaan-pertanyaan itu menjadi polemik dengan kemunculan kurikulum berbasis KKNI ini. Sebagai sebuah produk yang diujicobakan, perlu diadakan berbagai penelitian mengenai kelayakan berbasis KKNI untuk diaplikasikan di Indonesia. Hal itulah yang melatarbelakangi penelitian ini "Analisis Produk Pembelajaran Mata Kuliah Menulis Bahan Ajar Berbasis KKNI Program Studi Pendidikan Bahasa dan Sastra Indonesia FKIP Universitas HKBP Nommensen”.

\section{B. KAJIAN TEORI}

KKNI pada sistem pendidikan tinggi dinyatakan dalam UndangUndang Republik Indonesia nomor 12 Tahun 2012 tentang Pendidikan Tinggi yang selanjutnya disingkat UU Dikti 12/ 
2012. Pasal 29 UU Dikti 12/ 2012 menyatakan: 1) Kerangka Kualifikasi Nasional merupakan penjenjangan capaian pembelajaran yang menyetarakan luaran bidang pendidikan formal, nonformal, informal, atau pengalaman kerja dalam rangka pengakuan kompetensi kerja sesuai dengan struktur pekerjaan di berbagai sektor. 2) Kerangka Kualifikasi Nasional sebagaimana dimaksud pada ayat (1) menjadi acuan pokok dalam penetapan kompetensi lulusan pendidikan akademik, pendidikan vokasi, dan pendidikan profesi. 3) Penetapan kompetensi lulusan sebagaimana dimaksud pada ayat (2) ditetapkan oleh Menteri.

Penerapan pasal 29 UU Dikti 12/ 2012 dan Peraturan Presiden Nomor 8 tahun 2012 tentang KKNI dituangkan di dalam Peraturan Menteri Pendidikan dan Kebudayaan Republik Indonesia Nomor 73 Tahun 2013 tentang Penerapan Kerangka Kualifikasi Nasional Indonesia Bidang Pendidikan Tinggi. Pasal 10 ayat (3) Peraturan Menteri Pendidikan dan Kebudayaan Republik Indonesia Nomor 73 Tahun 2013 menyatakan bahwa dalam menerapkan KKNI di bidang kurikulum pendidikan tinggi, Direktorat Jenderal mempunyai tugas dan fungsi antara lain: 1) Memberikan masukan, konsultasi, pembimbingan/ pendampingan, mendorong dan memfasilitasi terjadinya proses penerapan KKNI bidang pendidikan tinggi; 2) Menyusun kebijakan, regulasi, dan panduan tentang penyusunan kurikulum program studi yang mengacu pada KKNI bidang pendidikan tinggi; 3) Mengevaluasi pelaksanaan kurikulum oleh program studi terhadap pencapaian jenjang kualifikasi pada KKNI bidang pendidikan tinggi; 4) Mengevaluasi deskripsi $\mathrm{CP}^{2}$ yang diusulkan oleh program studi sebagai dasar penetapan standar kompetensi lulusan program studi oleh Menteri; 5) Mengevaluasi secara berkala deskripsi CP yang diusulkan oleh program studi sebagai dasar penetapan standar kompetensi lulusan program studi oleh Menteri.

Pasal 35 ayat 2 UU Dikti 12/ 2012 tentang Kurikulum menyatakan bahwa Kurikulum Pendidikan Tinggi dikembangkan oleh setiap perguruan tinggi dengan mengacu pada Standar Nasional Pendidikan Tinggi untuk setiap program studi yang mencakup pengembangan kecerdasan intelektual, akhlak mulia, dan keterampilan. 
KKNI ini telah dijenjangkan menjadi 9 kualifikasi mulai dari Kualifikasi 1 sebagai kualifikasi terendah dan kualifikasi 9 sebagai kualifikasi tertinggi. Jenjang kualifikasi adalah tingkat capaian pembelajaran yang disepakati secara nasional, disusun berdasarkan ukuran hasil pendidikan dan/atau pelatihan yang diperoleh melalui pendidikan formal, nonformal, informal, atau pengalaman kerja (Kemendiknas, 2012). Khusus untuk S1 atau D4 berada pada level 6. Berikut jenjang kualifikasi untuk level 6. 1) Mampu mengaplikasikan bidang keahliannya dan memanfaatkan IPTEKS pada bidangnya dalam penyelesaian masalah serta mampu beradaptasi terhadap situasi yang dihadapi. 2) Menguasai konsep teoretis bidang pengetahuan tertentu secara umum dan konsep teoretis bagian khusus dalam bidang pengetahuan tersebut secara mendalam, serta mampu memformulasikan penyelesaian masalah procedural. 3) Mampu mengambil keputusan yang tepat berdasarkan analisis informasi dan data, dan mampu memberikan petunjuk dalam memilih berbagai alternatif solusi secara mandiri dan kelompok, serta bertanggung jawab pada pekerjaan sendiri dan dapat diberi tanggung jawab atas pencapaian hasil kerja organisasi.

Aksentuasi KKNI mengacu pada relevansi antara kompetensi dengan kebutuhan stakeholder. Kompetensi tersebut diakumulasi dalam tiga ranah kemampuan yaitu llmu pengetahuan (science), pengetahuan (knowledge), dan keterampilan (skill) (Dikti, 2012). KKNI program studi Pendidikan Bahasa dan Sastra Indonesia pada jenjang kualifikasi 6 (S1) memuat dua deskripsi kualifikasi, yakni deskripsi generik dan deskripsi spesifik.

Deskripsi generik memuat empat karakteristik, yakni (1) Mampu memanfaatkan IPTEKS dalam bidang keahliannya dan mampu beradaptasi terhadap situasi yang dihadapi dalam penyelesaian masalah, (2) Menguasai konsep teoretis bidang pengetahuan tertentu secara umum dan konsep teoretis bagian khusus dalam bidang pengetahuan tersebut secara mendalam, serta mampu memformulasikan penyelesaian masalah prosedural, (3) Mampu mengambil keputusan strategis berdasarkan analisis informasi dan data serta memberikan petunjuk dalam memilih berbagai alternative solusi, dan (4) Bertanggung jawab pada pekerjaan 
sendiri dan dapat diberi tanggung jawab atas pencapaian hasil kerja organisasi.

Sejalan dengan deskripsi generik di atas, maka deskripsi spesifik memuat karakteristik seperti berikut. Untuk deskripsi generik (1), deskripsi spesifiknya adalah mampu memanfaatkan IPTEKS yang relevan dalam lingkup Pendidikan Bahasa dan Sastra Indonesia untuk merancang, mengelola, memfasilitasi, dan mengevaluasi pembelajaran, serta aplikasi keilmuan. Untuk deskripsi generik (2) memuat dua karakteristik, yakni (a) Menguasai konsep-konsep dasar teori pendidikan bahasa Indonesia (pedagogik) dan substansi bidang ilmu bahasa dan sastra serta terapannya bagi peserta didik di sekolah menengah dan (b) Menguasai dasar-dasar perencanaan, pengelolaan, dan evaluasi pada pembelajaran bahasa Indonesia pada pendidikan menengah, dan memilih pendekatan, model, metode dan strategi pembelajaran, serta sistem evaluasi bagi peserta didik sekolah menengah, editor bahasa, pembawa acara, peneliti dan redaktur. Untuk deskripsi generik (3) memuat karakteristik mampu mengambil keputusan strategis berdasarkan analisis informasi dan data dalam menentukan berbagai alternatif pemenuhan kebutuhan belajar bagi peserta didik di sekolah menengah, editor bahasa, pembawa acara, peneliti, dan redaktur. Yang terakhir, Untuk deskripsi generik (4) dimuat karakteristik mampu menunjukkan kinerja dalam praktik pendidikan bahasa dan sastra Indonesia serta bidang terapannya, yang dapat dipertanggungjawabkan pada para pengguna, pemangku kepentingan, dan masyarakat dengan mengaplikasikan prinsip-prinsip dasar berpikir kritis dan kreatif.

Dalam hal ini, pengejawantahan KKNI tampak pada mata kuliah Menulis Bahan Ajar. Pada dasarnya, ada 3 capaian pembelajaran mata kuliah ini, yakni mampu menulis hand out, mampu menulis modul, dan mampu menulis LKS. Itu sebabnya, ketiga bahan ajar tersebut akan dikerjakan dan dianalisis dalam penelitian ini.

Ada tiga tahap menulis, yaitu tahap prapenulisan, tahap penulisan, dan tahap revisi atau penyempurnaan. Tahap-tahap tersebut mutlak harus dilalui agar tulisan berkualitas baik. Selain itu, penulis harus banyak ide, gagasan, dan obsesi tentang suatu hal yang akan ditulis. Oleh karena itu menulis tergolong 
sebuah proses kreatif. Sebagai proses kreatif, penulisan karya ilmiah memuat empat tahap, yaitu (1) tahap persiapan, (2) tahap inkubasi, (3) tahap iluminasi, dan (4) tahap verifikasi/ evaluasi. Secara umum, struktur modul adalah sebagai berikut.

1. Halaman Sampul

2. Halaman Francis

3. Kata Pengantar

4. Daftar Isi

5. Peta Kedudukan Modul

6. Glosarium

\section{PENDAHULUAN}

1. Deskripsi

2. Prasarat

3. Petunjuk Penggunaan Modul

4. Tujuan Akhir

5. Kompetensi

6. Cek Kemampuan

\section{PEMBELAJARAN}

1. Rencana Belajar Peserta didik

2. Kegiatan Belajar

a. Kegiatan Belajar

1) Tujuan Kegiatan Pembelajaran

2) Uraian Materi

3) Rangkuman

4) Tugas

5) Tes Formatif

6) Kunci Jawaban Formatif
7) Lembar Kerja

b. Kegiatan Belajar 2

c. Kegiatan Belajar n

III. EVALUASI

1. Kognitif Skill

2. Psikomotor Skill

3. Attitude Skill

4. Produk/Benda Kerja Sesuai Kriteria Standart

5. Batasan Waktu Yang Telah

Ditetapkan

6. Kunci Jawaban

IV. PENUTUP

Daftar Pustaka

Perangkat pembelajaran yang baik menurut Gagne dan Briggs (dalam Sarimanah, 2009) mengandung lima komponen yang disebut anchor point, yakni tujuan pengajaran (Kontrak Kuliah, Silabus, dan SAP), materi pelajaran (Bahan Ajar), Pendekatan, Strategi, Model dan Metode Pembelajaran, Media Pembelajaran, serta Evaluasi. Tujuan pembelajaran merupakan indikasi tercapainya perubahan perilaku atau kompetensi pada mahasiswa setelah mengikuti kegiatan pembelajaran dan tujuan dirumuskan dalam bentuk pernyataan 
atau deskripsi yang spesifik. Penentuan materi pelajaran mesti berdasarkan tujuan yang hendak dicapai dan hal itu dimuat dalam bahan ajar yang harus dipelajari mahasiswa dalam rangka mencapai standar kompetensi yang telah ditentukan. Pendekatan, strategi, model, dan metode pembelajaran digunakan untuk membangun interaksi. Keaktifan mahasiswa tentu mencakup kegiatan fisik dan mental, individual dan kelompok. Sebagai penyaji dan penyalur pesan, media belajar dalam hal-hal tertentu bisa mewakili dosen dalam menyajikan informasi belajar kepada mahasiswa. Jika program media itu didesain dan dikembangkan secara baik, maka fungsi itu akan dapat diperankan oleh media meskipun tanpa keberadaan dosen. Tujuan evaluasi adalah untuk menentukan kualitas sesuatu, terutama yang berkenaan dengan nilai dan arti. Dalam hal ini, tujuan pembelajaran menjadi bahan evaluasi untuk mengetahui tingkat pencapaian pembelajaran.

\section{METODE PENELITIAN}

Penelitian ini merupakan penelitian evaluasi program yang bersifat kualitatif. Tentunya, baik paradigma dan analisis yang digunakan akan diuji dengan pendekatan kuantitatif. Adapun produk yang dianalisis adalah modul, LKS, dan hand out. Subjek penelitian ini terdiri atas dua kelompok, yakni mahasiswa semester lima Prodi Bahasa dan Sastra Indonesia T.A. 2016/ 2017 sebagai subjek untuk uji coba kelompok terbatas. Penelitian ini akan dilakukan di Universitas HKBP Nommensen Medan. Penelitian ini mengumpulkan produk kerja mahasiswa selama satu semester berupa LKS, Modul, dan Hand Out, lalu memberikan penilaian dan menjadikan nilai tersebut sebagai data penelitian. Langkah-langkah yang dilakukan dalam menganalisis data adalah:

1. Melakukan analisis data terhadap nilai produk kerja

2. Membuat nilai presentase mahasiswa.

3. Menyimpulkan hasil penelitian

\section{HASIL DAN PEMBAHASAN}

Penelitian ini mengadakan analisis terhadap tiga produk kerja mata kuliah Menulis Bahan Ajar, yakni LKS, modul, dan Hand out. Analisis tersebut disesuaikan dengan jenjang nilai yang ditetapkan pada Kurikulum berbasis KKNI, yakni sebagai berikut. 
Tabel 1. Jenjang Penilaian Kurikulum Berbasis KKNI

\begin{tabular}{l|cc|c}
\hline No. & Rentang Nilai & Bobot \\
\hline 1 & $80 \quad \mathbf{A} 100$ & 4,00 \\
\hline 2 & 76 & $\mathbf{A}^{-}<80$ & 3,75 \\
\hline 3 & 72 & $\mathbf{A} / \mathbf{B}<76$ & 3,50 \\
\hline 4 & $68 \quad \mathbf{B}^{+}<72$ & 3,25 \\
\hline 5 & 65 & $\mathbf{B}<68$ & 3,00 \\
\hline 6 & 62 & $\mathbf{B}^{-}<65$ & 2,75 \\
\hline 7 & 59 & $\mathbf{B} / \mathbf{C}<62$ & 2,50 \\
\hline 8 & 55 & $\mathbf{C}^{+}<59$ & 2,25 \\
\hline 9 & $50 \quad \mathbf{C}<55$ & 2,00 \\
\hline 10 & 40 & $\mathbf{D}<50$ & 1,00 \\
\hline 11 & 0 & $\mathbf{E}<40$ & 0,00 \\
\hline
\end{tabular}

Penilaian ketiga bahan ajar dalam penelitian ini disesuaikan dengan struktur yang telah dijelaskan di atas. Secara sederhana, ketiga bahan ajar tersebut disusun atas beberapa komponen. Hand out hanya terdiri dari dua komponen, yakni judul (identitas) dan informasi pendukung. Sedangkan, modul sifatnya lebih kompleks karena terdiri atas tujuh komponen, yakni judul, petunjuk belajar, kompetensi dasar atau materi pokok, informasi pendukung, latihan, tugas, atau langkah kerja, dan penilaian. Selanjutnya, LKS terdiri atas enam komponen, yakni judul, petunjuk belajar, kompetensi dasar atau materi pokok, informasi pendukung, tugas atau langkah kerja, dan penilaian. Berdasarkan komponenkomponen tersebut diperoleh hasil penilaian bahan ajar sebagai berikut.

Tabel 2. Persentase Penilaian Bahan Ajar

\begin{tabular}{c|c|c|c|c|c|c|c|c}
\hline No & Produk & A & A & A/B & B $^{+}$ & B & B & B/C \\
- & & & & - & \\
\hline
\end{tabular}




\begin{tabular}{l|l|c|c|c|c|c|c|c}
\hline 1 & Hand & $\begin{array}{c}30 \\
(35,2)\end{array}$ & 0 & $\begin{array}{c}32 \\
(37,6)\end{array}$ & $\begin{array}{c}11 \\
(12,9)\end{array}$ & $\begin{array}{c}1 \\
(1)\end{array}$ & 0 & $\begin{array}{c}11 \\
(12,9)\end{array}$ \\
\hline 2 & Modul & 58 & 0 & 7 & 3 & 0 & 0 & 17 \\
& & $(68,2)$ & & $(8,2)$ & $(3,5)$ & & & $(20)$ \\
\hline 3 & LKS & 62 & 0 & 3 & 4 & 4 & 0 & 12 \\
& & $(72,9)$ & & $(3,5)$ & $(4,7)$ & $(4$, & & $(14,1)$ \\
& & & & & 7 & & \\
\hline
\end{tabular}

Berdasarkan tabel tersebut tampak bahan ajar tersebut. Hal itu disebabkan, bahwa nilai penulisan hand out ada peneliti mengadakan latihan penulisan pada grade A sebanyak 35,2 \%, pada hand out di awal sehingga subjek penulisan modul $68,23 \%$, dan penulisan LKS $72,9 \%$. Perlu diketahui bahwa meskipun hand out hanya memiliki dua komponen, tidak berarti nilai subjek penelitian lebih tinggi pada penulisan masih belajar menulis, sedangkan penulisan modul dan LKS diadakan di akhir sehingga nilainya lebih tinggi sebab subjek sudah mendapat pengalaman pada penulisan hand out sebelumnya.

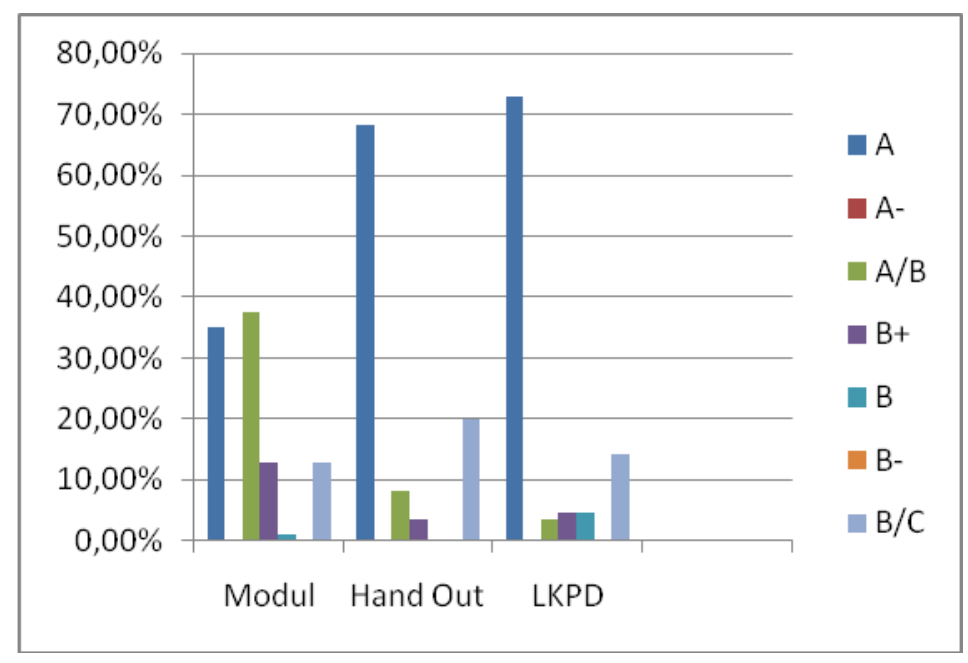

Gambar 1. Grafik Perolehan Nilai Bahan Ajar

Selain data di atas, wawancara juga dilakukan untuk memperoleh hasil penelitian. Adapun hasil wawancara mengarah pada kesulitan yang dialami siswa dalam menulis bahan ajar yang disimpulkan pada beberapa poin berikut: Kesulitan menulis modul: 1) Kesulitan dalam menuliskan apa saja 
cakupan yang dituliskan dalam pendahuluan bagian deskripsi. 2) Kesulitan menggambar peta konsep di bagian awal modul yang harus mencakup keseluruhan isi modul. 3) Kesulitan dalam menyesuaikan kompetensi dengan masing-masing $\mathrm{KD}$ yang digunakan sesuai silabus. 4) Kesulitan membuat soal atau pertanyaan pada cek kemampuan. 5) Kesulitan dalam mengembangkan dua KD menjadi beberapa kegiatan pembelajaran. 6) Kesulitan dalam membuat bagan atau ilustrasi yang sesuai dengan materi yang dimuat. 7) Kesulitan dalam membuat soal-soal pada evaluasi supaya tidak tumpang tindih dan sesuai materi yang dimuat.

Selanjutnya, kesulitan menulis hand out: 1) Kesulitan dalam menyesuaikan $\mathrm{KD}$, silabus dan buku yang mendukung. 2) Kesulitan dalam membuat ringkasan materi yang harus lengkap tetapi singkat. 3) Kesulitan dalam menemukan sumber (buku) yang sesuai dengan materi. 4) Kesulitan dalam membuat contoh yang banyak yang sesuai dengan materi, karena pada umumnya handout harus kaya akan materi.

Kesulitan dalam menulis Lembar Kerja Peserta Didik (LKPD): 1)
Kesulitan dalam membuat soal yang representatif (menyeluruh). 2) Kesulitan dalam membuat soal yang lengkap terdiri dari C1 sampai C6. 3) Dalam pembuatan jenis soal yang bersifat objektif membutuhkan waktu yang lama dan taraf kesulitan yang lebih tinggi.

\section{E. KESIMPULAN}

Berdasarkan penelitian yang telah dilakukan dapat disimpulkan bahwa nilai penulisan hand out ada pada grade A sebanyak 35,2 \%, penulisan modul $68,23 \%$, dan penulisan LKS 72,9\%. Penulisan LKPD tampak lebih tinggi dimungkinkan karena mahasiswa lebih mudah membuat soal daripada mengembangkan materi. Kesimpulan itu diperkuat dengan kesulitan-kesulitan yang dialami siswa dalam pengerjaan proyek ini.

\section{F. SARAN}

Penelitian ini tidak cukup mampu memfasilitasi keingintahuan para pembaca dalam hal produktivitas penerapan KKNI, dibutuhkan penelitian lain yang lebih mendalam terkait hal itu. Selain itu, dibutuhkan perangkat pembelajaran yang lebih mumpuni dalam mengarahkan mahasiswa menulis bahan ajar. 


\section{DAFTAR PUSTAKA}

Direktorat Pendidikan Tinggi. 2012.

Buku Pedoman Kerangka

Kualifikasi Nasional

Indonesia. Jakarta: DIKTI.

Program Studi Pendidikan Bahasa

Indonesia. 2016. Kurikulum

Program Studi Pendidikan

Bahasa Indonesia Berbasis

KKNI. Medan: Universitas

HKBP Nommensen.

Mustafa \& Paulin. 2011.

Pengembangan Kurikulum

Berbasis Kompetensi pada

Perguruan Tinggi. UNG .

Sarimanah, E., dkk. 2009.

Pengembangan Model

Perencanaan Pembelajaran

Berbasis Strategi Metakognitif

dalam Mata Kuliah

Perencanaan Pengajaran

Bahasa Indonesia melalui

Implementasi Program Lesson

Study. 